$11-30-2017$

\title{
Do the Lessons From Micro-Conflict Literature Transfer to High Crime Areas?: Examining Mexico's War on Drugs
}

Muhammad Nasir

Marc Rockmore

Chih Ming Tan

University of North Dakota, chihming.tan@UND.edu

\section{How does access to this work benefit you? Let us know!}

Follow this and additional works at: https://commons.und.edu/ef-fac

Part of the Development Studies Commons

\section{Recommended Citation}

Muhammad Nasir, Marc Rockmore, and Chih Ming Tan. "Do the Lessons From Micro-Conflict Literature Transfer to High Crime Areas?: Examining Mexico's War on Drugs" (2017). Economics \& Finance Faculty Publications. 16.

https://commons.und.edu/ef-fac/16

This Article is brought to you for free and open access by the Department of Economics \& Finance at UND Scholarly Commons. It has been accepted for inclusion in Economics \& Finance Faculty Publications by an authorized administrator of UND Scholarly Commons. For more information, please contact und.commons@library.und.edu. 


\title{
Do the Lessons From Micro-Conflict Literature Transfer to High Crime
}

\author{
Areas?: Examining Mexico's War on Drugs ${ }^{\#}$
}

\author{
Muhammad Nasir ${ }^{*} \quad$ Marc Rockmore $^{+} \quad$ Chih Ming Tan ${ }^{\perp}$
}

\begin{abstract}
Exposure to political violence is known to affect behavioral parameters. The effects of high levels of criminal violence, however, are largely unknown. We examine the effects of Mexico's war on drugs on risk aversion, mental health and pro-social behavior. Using a difference-in-differences (DiD) approach, we find that the post 2006 surge in violence significantly increased risk aversion and reduced trust in civic institutions without any simultaneously strengthening of kinship relationships. We explore the possibility that deterioration of mental health due to exposure to violence explains the changes in risk aversion, but find no such effect.
\end{abstract}

Keywords: violence, risk aversion, social capital, mental health, Mexico

JEL Classification: A12, D03, D81, O12

\footnotetext{
\# This work was supported by the Greg and Cindy Page Faculty Distribution Fund to Chih Ming Tan. A previous version of this work was circulated with the title: "It's No Spring Break in Cancun: The Effects of Exposure to Violence on Risk Preferences, Pro-Social Behavior, and Mental Health". We thank the editor and two anonymous reviewers for insightful comments. Any remaining errors are solely attributable to the authors. The data and programs required to replicate the results are available upon request.

*Pakistan Institute of Development Economics, Quaid-i-Azam University Campus, Islamabad 44000, Pakistan. ${ }^{+}$Department of Economics, Clark University, 950 Main Street, Worcester, MA 01610. Corresponding Author: mrockmore@clarku.edu.

${ }^{\perp}$ Department of Economics, University of North Dakota, 293 Centennial Drive Stop 8369, Grand Forks, ND 58202.
} 


\section{INTRODUCTION}

The negative and persistent effects of violence on micro-development outcomes, including behavioral parameters, are well established by a literature on civil conflict and other types of political violence. In recent years, however, the global composition of violence has changed with a decrease in political violence but an increase in criminal violence. This is particularly true in many areas of Latin America and the Caribbean (LAC) where high levels of violence from gangs and drug traffickers have replaced large-scale political violence (World Bank 2011). The effects of criminal violence on behavioral parameters are largely unstudied. Consequently, it is unclear whether and to what extent the findings of the micro-conflict literature transfer to areas with high criminal violence given the differences in the nature and motivation of the underlying violence (Kan 2012).

There are reasons to believe that directly transferring the lessons learnt from the literature on conflict to the context of violent crime may be problematic. First, the widespread use of geographically aggregate measures of violence in the micro-conflict literature likely overestimates both the magnitude and the statistical significance for exposure to criminal violence. The estimated coefficients from these aggregate measures depend directly on the relative ratios of directly and indirectly affected people within each geographical area (Moya 2015; Rockmore et al. 2016). However, compared to conflict exposure, relatively fewer people directly experience violence in 'high' crime areas. Second, even for research which measures individual exposure to violence, important differences may exist. The mental health literature emphasizes not only the magnitude of the trauma (which is likely more severe during conflicts) but also the distinct number of trauma experienced and the duration of the exposure (Goenjian et al. 2005; Hoge et al. 2004; Kaysen et al 2010; Mollica et al 1998). Compared to individuals in high crime areas, people in conflict settings 
are more likely to be exposed to a broader range of traumatic events for longer durations making the effects of direct exposure in conflict areas more severe.

We use the recent surge of drug-related violence in Mexico to consider whether the lessons derived from the micro-conflict literature transfer to areas with criminal violence. In particular, we examine the effects of (indirect) exposure ${ }^{1}$ to criminal violence on two of the key outcomes from the micro-conflict literature, risk aversion and social behavior, and one of the primary hypothesized channels, mental health.

The Mexican setting offers several advantages. First, following President Calderon's election in 2006 and his subsequent crackdown on drug traffickers, homicide rates surged from the relatively stable pre-crackdown levels. Consequently, there is a clear start to the 'treatment'; i.e., the abrupt increase in rates of homicides. Second, the location and levels of violence were not determined by individual or local characteristics (Brown 2015; Velásquez 2015). Rather, as arrests and deaths weakened drug trafficking organizations, rival organizations and internal factions fought for control of territory and drug routes (Guerrero 2012). This exogenous spatial and temporal variation in the levels of violence allows for clear identification of treatment effects from changes in local homicide rates. Third, the Mexican Family Life Survey, a high quality panel survey, was fielded immediately preceding the violence (2005-6) and during the peak levels of violence (2009-12). Consequently, while other studies typically assume that there are no systematic differences in the distribution of potential outcomes across treatment and comparison groups due to unobserved confounders, we are able to employ the weaker assumption of requiring only that the outcomes share common pre-treatment trends across the two groups for identification of the treatment effect.

\footnotetext{
${ }^{1}$ As we subsequently discuss, despite the surge in violence, very few people were directly exposed to violence. Consequently, 'exposure' refers to the increased insecurity.
} 
Although we find that 'exposure' to high levels of criminal violence negatively impacts the studied development outcomes, there are important differences with the previous literature on political violence. We first examine the effects on risk aversion. Risk aversion, along with other behavioral parameters, has traditionally been considered as being largely fixed (Stigler and Becker 1977). However, recent research finds that behavioral parameters can be changed by large shocks (Cameron and Shah 2013; Eckel et al. 2009; Malmendier and Nagel 2011) with risk aversion responding to both direct (Callen et al. 2015; Moya 2015; Rockmore et al. 2016; Voors et al. 2012) and indirect (Jakiela and Ozier 2015; Rockmore et al. 2016) exposure to violence. Similar to prior micro-conflict studies, we find that exposure to violence causally affects risk aversion (increases the likelihood of being risk averse by 5 percent on average).

Our results are also broadly consistent with the existing research on the effects of criminal violence on risk aversion. In the first such study, Padilla (2012) uses historical individual-level experience with violence. Due to our use of a difference-in-difference methodology our results are not directly comparable as the individual level experiences are 'differenced' away. Potential concerns regarding selection into violence based on unobservables, such as in Padilla (2012), have been more recently addressed in two contemporaneously developed papers (on Mexico) which also use local homicide rates. Manian (2015) focuses on the risk behavior of sex workers (specifically, inconsistent condom use) and finds that increased violence reduces sexual risk-taking. Most comparable to our work is Brown et al. (2017) who examine the effects of an increase in municipal homicide rates on risk aversion. While there are slight differences in the categorization of risk aversion, our results are broadly similar.

We differ, however, from much of the micro-conflict literature with respect to the effect of exposure on mental health. In addition to being an important outcome in itself, mental health is 
frequently hypothesized to be a (or even the) channel from exposure to violence to changes in behavioral outcomes (Callen et al. 2015; Voors et al. 2012). However, this hypothesis has only been directly examined by Moya (2015) (anxiety disorders) and Rockmore et al. (2016) (psychosocial distress) who find that mental health is a channel through which violence affects risk aversion. $^{2}$

Using a 20 questions mental health module based on the Center for Epidemiologic StudiesDepression scale (CES-D; Radloff 1977) to measure depressive symptoms/anxiety among individuals, we examine whether the changes to risk aversion in Mexico are similarly explained by a deterioration of mental health. In contrast to these studies, we find no effect of exposure to violence on mental health. In part, this is likely due to the high levels of direct exposure in the prior studies as compared to our measure of indirect exposure. However, since we find large changes in risk aversion, this suggests that while mental health may be a channel through which violence affects risk aversion, it is unlikely to be the only channel nor is it potentially necessary for these changes to take place.

Finally, we investigate the effects of exposure on the preferences of individuals for civic engagement and social capital at various social distances. These factors, particularly trust (Cassar et al. 2013; De Luca and Verpoorten 2015; Nunn and Wantchekon 2011; Rohner et al. 2013; Voors et al. 2012) and political participation (Bellows and Miguel 2009; Bateson 2012; Blattman 2009; Morrison and Rockmore, 2016), have been studied by the literature on violence. In their recent review of the literature on violence and social cooperation, Bauer et al. (2016) conclude that

\footnotetext{
${ }^{2}$ Whereas Moya (2015) and Rockmore et al. (2016) examine whether exposure to violence affects risk aversion through changes in mental health, an earlier version of Brown et al. (2017) examines the related question of whether the level of emotional well-being determines the effects of violence on risk aversion and did not find a statistically significant relationship.
} 
violence leads to greater cooperation and likely increases in-group prosocial behavior. However, we do not find any corresponding increase in cooperation. Rather, we find no effect on in-group cooperation and increased support for the disregard of laws.

Taken together, our findings suggest important costs arising from the increased criminal violence in Mexico and, potentially, more broadly in LAC. Both risk aversion and social behavior are key inputs for economic growth. Risk aversion affects investment decisions and the willingness to seize new opportunities (Skriabikova et al. 2014). Similarly, social behavior, such as trust, cooperation, and inter-group exchanges, underpin market development and all manners of economic interaction (see, for instance, Algan and Cahuc 2010; Fafchamps 2006; Henrich et al. 2010; Knack and Keefer 1997; Zak and Knack 2001) including informal insurance mechanisms. Consequently, violence engenders a negative externality on growth via these behavioral changes and may partially explain the decreased economic activity attributed to the increased drug violence in Mexico (BenYishay and Pearlman 2013; Calderon et al. 2013; Rios 2015).

The remainder of the paper is organized as follows: section 2 briefly describes the evolution of homicide rates in Mexico, section 3 describes the data and explains the difference-in-differences methodology employed, section 4 discusses our main findings as well as robustness checks and results on heterogeneity, and section 5 concludes.

\section{VIOLENCE IN MEXICO}

Before the 2006 election of Felipe Calderón to the presidency and his subsequent crackdown on organized crime groups (OCGs), violence levels were relatively stable (Figure 1: yearly variation). Upon becoming President, Calderón launched a military-led crackdown on OCGs which is believed to have led to the subsequent spike in violence (Molzahn et al. 2012; Guerrero 2011). In 
the subsequent four years, the number of homicides roughly tripled, from approximately 8,500 to nearly 25,000 between 2007 and 2010 .

Prior to the crackdown, the drug cartels operated in an oligopolistic equilibrium with relatively stable levels of violence (Velásquez 2015). The crackdown increased the violence through three channels: direct confrontations between the military and OCGs, internal power struggles following the arrest/death of major leaders, and attempts by rival organizations to take market share from weakened rival organizations (Guerrero 2012). This cycle of violence was self-reinforcing: crackdowns led to violence which incited both further government actions and confrontations among remaining OCGs. The power struggles also led to a splintering of OGCs as the number increased from 6 to 16 within four years (2007-2010). In turn, this further reinforced the cycle of violence (Guerrero 2011).

This violence spilled over onto the civilian population in several ways. First, the increased number of OCGs reduced profit margins and pushed them into other criminal activities including extortions, kidnapping and thefts to increase profits (Guerrero 2011; Molzahn et al. 2012). Second, civilians were targeted to instill fear and hinder cooperation with the government (Brown 2015). Lastly, civilians were caught in the cross-fire between heavily armed gangs. The violence was not limited to men as women were also directly targeted through kidnappings, murders and rapes, and indirectly affected through family exposure (United Nations 2011; Velásquez 2015).

The violence not only escalated over time but also spread throughout the country. For example, only 48 municipalities reported 12 or more homicides in 2007. By 2010, this level of homicides occurred in 148 municipalities (Velásquez 2015). Maps 1-3 show the spatial spread of violence for 2002, 2005 (the year before President Calderon's term), and 2009 respectively. By 2009, the crackdown had reached full strength as had the reinforcing feedback. This led to violence spikes 
in many previously unaffected municipalities. Moreover, the increase in violence was not uniform across municipalities nor time.

While it is not possible to verify, a large portion of the increased homicides are believed to directly result from the crackdown and the violence it engendered. ${ }^{3}$ This violence was driven by the OCG's and events (such as major arrests) which were beyond the influence of ordinary citizens.

\section{DATA AND METHODOLOGY}

\subsection{Data}

We primarily rely on the Mexican Family Life Survey (MxFLS), a longitudinal and national representative panel with surveys in 2002 (MxFLS1), 2005-06 (MxFLS2), and 2009-12 (MxFLS3)

respectively. ${ }^{4}$ We focus on the MxFLS2 and MxFLS3 since data on risk aversion and pro-social behavior (discussed further in later sections) are only available for these rounds. However, we also include data from MxFLS1 in some analyses since data for mental health (also discussed later) are available for all three rounds. These data provide information for the pre-violence (2005-2006) and peak violence periods (2009-2012) thereby allowing us to exploit a difference-in-differences strategy (which we detail in the next section) in order to identify average treatment effects.

The 2002 baseline survey collected data from 8,440 households consisting of 35,600 individuals in 150 communities of 16 states across Mexico (Rubalcava and Teruel 2013). The individuals in baseline households were followed in subsequent waves. The attrition rates were very low with $89 \%$ and $87 \%$ of respondents re-interviewed in the second (2005-06) and third waves (2009-12)

\footnotetext{
${ }^{3}$ A variety of estimates exist for the share of drug violence in total homicides, ranging from 30 to 90 percent. However, it is often not possible to accurately distinguish the cause of violent deaths making any estimates inherently unreliable. Irrespective of the source of homicide data, however, there is a notable increase in homicides after the 2006 election of Calderon.

${ }^{4} 94 \%$ of the data for the third wave was collected in the years 2009 and 2010 (Brown 2015).
} 
respectively. We restrict the sample to adults (15 and older) since children did not answer the risk preference, mental health, or social behavior modules. After cleaning the data and dropping observations with missing information, our final sample size consists of 8,650 individuals. ${ }^{5}$

We supplement the MxFLS data with data on the monthly municipal level homicide rate from the Mexican National Institute for Statistics and Geography (INEGI in spanish) which records all intentional homicides. These data, however, report information only on registered homicides. This could be an important concern if the drug cartel-related homicides are significantly underreported. Velásquez (2015) addressed this concern by comparing the INEGI data with the data on homicides related to organized crime (which is reported by the President's Office) and finds similar trends. We use the former data instead of the latter since they are available for a longer span of time (19902012) thus allowing us to examine both the pre-escalation and escalation periods.

\subsubsection{Violence and Treatment Assignment}

Although homicide rates more than tripled over this period, only a small fraction of people were ever directly exposed to homicides. For instance, in our sample, not a single household member died due to a violent incident outside of their household. ${ }^{6}$ This is not surprising as the median homicide rate was only 10.6 per 100,000 inhabitants. Consequently, the significant increase in the homicide rate increased the potential of being a victim and, most likely, the perceived insecurity. We therefore interpret our treatment as the indirect effect of violence. ${ }^{7}$ Moreover, our use of a

\footnotetext{
${ }^{5}$ This varies based on outcome variables.

${ }^{6}$ Unfortunately, there is no question about violence within the household. More broadly, less than $5 \%$ of the sample reporting 'ever [having] been assaulted, robbed, or have you been a victim of any violent incident, outside your household, plot, or business since 2005 to date.' The vast majority (93\%) of these reported having been robbed or assaulted.

${ }^{7}$ Note that indirect exposure to violence may represent the bulk of the 'costs' of violence (Rockmore, 2016).
} 
geographical measure of exposure to violence also matches the literature as few studies use data on individual level exposure.

As noted earlier, the increase in violence was not homogenous; it occurred in different areas at different points in time. Consequently, our 'treatment' relates to the lowest geographical level for which the homicide rate is available: the municipality. ${ }^{8}$ Specifically, we use the number of homicides per 10,000 inhabitants in a municipality in twelve months prior to the interview date as our continuous measure of treatment.

\subsubsection{Risk Preferences}

Risk preferences are constructed using the risk modules from the second and third waves of the MxFLS data. These are designed as a simple gamble-choice task (Eckel and Grossman 2008). The survey played hypothetical games by asking respondents to choose sequentially between two different lotteries. ${ }^{9}$ The risk module from the second wave is shown in Figure A1 in the Appendix. In a series of games, the respondents are offered two choices: a safe option of a bag with two chips of equal values of 1,000 pesos while the other bag varies both in terms of risk and expected payoffs. This in line with the seminal work of Binswanger (1980), as well as the micro-conflict literature on risk aversion, which suggests that higher expected payoff can be earned only at the cost of higher variance. At each stage, respondents are offered a choice between the two choices. The most risk averse person chooses the safe option throughout and ends up at the terminal point in the lower left corner (category 1). The least risk averse person ends up at the terminal point in the

\footnotetext{
${ }^{8}$ Since selection into violence is unlikely to be random, we do not focus on individual level exposure.

${ }^{9}$ A possible concern is that the absence of real financial rewards affects responses (Holt and Laury 2002). Hamoudi and Thomas (2006) examine this by comparing survey answers with experimentally derived measures of preferences using a subset of the MxFLS households. They find that preferences measured using the survey and the experiment are highly correlated.
} 
lower right corner (category 5). Consequently, the terminal points characterize an ordinal ranking of risk preferences among the respondents.

Similar categories are created using the risk module from the third wave. Although the payoffs in the third wave differed, they are measured in the same way. Consequently, there is a common shift for everyone in the third wave. With our difference-in-difference methodology, this common shift is 'differenced' away so that, as in the second wave, we recover the relevant average treatment effect. Finally, the ordered variable is transformed into a binary variable by combining the two most risk averse groups $(=1,0$ otherwise). Hence, a positive average treatment effect implies an increase in risk aversion due to exposure to violence. Since the threshold for conversion is arbitrary, we subsequently examine an alternate specification.

\subsubsection{Mental Health}

We construct a measure of mental health based on the twenty-question module where the respondent reports his/her own perception about emotional status in the past four weeks. This module is based on the Center for Epidemiologic Studies-Depression scale (CES-D). The CES-D was first developed by Radloff (1977) and was designed for inclusion in surveys. It has been described as 'the workhorse of depression [psychiatric] epidemiology' and validated by the American Psychological Association. ${ }^{10} 11$ The MxFLS module was also authenticated by the Mexican Institute of Psychiatry (Calderon 1997) to identify anxiety and moderate and severe depression.

Each question is given a score from 1 to 4 (with 1 being normal and 4 being severe). These are added to construct the depression index ranging between 20 and 80. In clinical settings, the CES-

\footnotetext{
${ }^{10} \mathrm{http}: / /$ cesd-r.com/about-cesdr/

${ }^{11}$ Steffick (2000) extensively discusses the CES-D.
} 
$\mathrm{D}$ is associated with a particular cutoff value (the precise value depends on how the particular CES-D or variant is measured) where values above that cutoff indicate elevated risk for clinical depression. In the MxFLS context, according to the guidelines of the National Institute of Psychiatrics, the CES-D score has been partitioned as follows: 1=normal (20-35); 2=anxious (3645); $3=$ moderately depressed (46-65); and 4=severely depressed (66-80). In our benchmark exercises, we consider a binary dependent variable (depression indicator) by combining the moderately and severely depressed categories into one category and assign the category a value of 1; 0 otherwise. A positive average treatment effect on this outcome therefore implies a deterioration in mental health due to exposure to violence. For robustness, we also consider an alternate threshold and directly using the underlying CES-D scores as the outcome variable of interest.

\subsubsection{Social Behavior}

While the broader literature on trust and cooperation typically uses variations of Almond and Verba's (1963) 'trust question' (Capra et al. 2008), this is often not true of the micro-conflict literature. With the exception of several studies using large multi-country surveys (e.g. Afrobarometer, the Life in Transition Survey), the micro-conflict literature often relies on proxies, reported behavior, and/or experimental evidence. ${ }^{12}$

Similar to much of this literature, we rely on proxies for trust since the MxFLS does not contain the 'trust question'. We focus on two questions answered by respondent using a 4 point Likert scale. Specifically, respondents are asked whether (i) 'Laws are made to be broken', and (ii) 'No

\footnotetext{
${ }^{12}$ Bauer et al. (2016) identify 7 studies which use survey measures of trust: only 4 used variations of the 'trust question.' Cilliers et al. (2016), which is not included in the Bauer et al., uses a mix for 'trust' and non-trust questions for their index of generalized trust in the community. Similarly, Silva and Mace (2014) rely on survey behavior of real life actions as their measure of cooperation.
} 
one should get involved in family or friends' problems'. In our baseline exercises, we convert these survey responses into binary dependent variables where the 'completely agree' and 'agree' responses are grouped together and assigned the value of $1 ; 0$ otherwise. ${ }^{13}$

These statements can be interpreted as eliciting individual behavioral preferences that map into various forms of social capital (see, Dasgupta 2005; Durlauf and Fafchamps 2004); in particular, the deeply related concepts of social norms and trust. Statement (i) reflects the individual's view of her relationship with the broader civic (legal) institutions. ${ }^{14}$ To the extent that exposure to violence results in the breakdown of conformity to social norms embedded in formal legal institutions, we would expect to see a reduction in the stock of generalized trust in society (Knack and Keefer 1997).

Statement (ii) addresses a special type of social network: kinship networks. We will refer to statement (ii) as 'private social capital' in Section 4.3 below. Since it represents cooperation within a homogenous group only, Statement (ii) is arguably a proxy for 'bonding social capital' since this sort of capital refers to relationships between members of a network who share some similarity (such as family or friendship) (Putnam, 2000). ${ }^{15}$ Collectively, therefore, the two statements allow us to investigate how increased insecurity changes individual pro-social behavioral preferences at different social distances.

\subsection{Methodology}

\footnotetext{
13 There is also an option of responding 'don't know'. We drop individuals who responded with 'don't know' to preserve the interpretability of the binary variable $(<1 \%$ of the sample).

14 This 'classification' of the question follows Knack and Keefer (1997) who similar interpret several questions on breaking the law.

${ }^{15}$ This classification is also similar to Bauer et al (2006) who 'define in-group members as people from the same family, village, class, and ethnic group' (p. 260).
} 
Typical of the literature, we use a linear differences-in-difference (DiD) model (Bertrand et al 2004) that has been generalized to a continuous treatment:

$$
\text { Outcome }_{i, j, t}=\beta \text { Homicide Rate } \text { R }_{j, t}+\delta X_{i, j, t}+\theta W_{j, t}+Z_{t}+\eta_{j}+\epsilon_{i, j, t}
$$

Where Outcome $_{i, j, t}$ is the relevant outcome for individual $i$ living in municipality $j$ in survey $t$. As noted earlier, we examine three broad outcomes: risk aversion, mental health and social behavior (private social capital and civic norms of cooperation). Homicide rate $e_{j, t}$ is the measure of violence defined at the municipality level. We primarily measure it using the (continuous) municipal homicide rate (per 10,000 inhabitants). As we subsequently discuss, in our robustness checks we also use binary measures for above/below the median and third quartile municipal homicide rate. The dummy variable, ++ , denotes the treatment wave of the MxFLS. Consequently, $\beta$ represents the average treatment effect on the treated.

$X_{i, j, t}$ controls for individual and household level characteristics. These include the gender, age and age squared, education level, and marriage and employment status of individual $i$. In certain specifications, we further control for municipal characteristics represented by $W_{j, t}$ : border with the US, agriculture production area, housing (total private dwellings), average household size, conviction and literacy rates, and health care access. Finally, $\eta_{j}$ and $Z_{t}$ are municipal and time fixed effects, respectively.

As noted earlier, the levels of violence in Mexico were lower than those in many conflicts. Consequently, one potential concern is that the effects of violence only occur after a particular 'violence threshold'. Consequently, we examine the robustness of our results by replacing our continuous measure of homicides with binary treatment variables using two thresholds: the median 
municipal homicide level in 2009 (10.6 per 100,000 inhabitants) and the third quartile in 2009 (18.9 per 100,000$)$.

Finally, we note that identification assumes an exogenous surge in violence. It is possible that the surge in violence was related to unobserved changes in characteristics at the level of the municipality. Brown (2015) formally examines this issue using data on pre-escalation trends for 135 baseline municipalities of MxFLS to predict each municipality's homicide rate in 2009 along with the change in the homicide rate between 2005 and 2009. He does not find any evidence that the pre-escalation trends in the observed characteristics of municipalities were related to future homicide rates. ${ }^{16}$ This evidence provides some assurance that the surge in violence may be exogenous to municipalities' characteristics. ${ }^{17}$

\section{RESULTS}

\subsection{Violence and Risk Preference}

The literature on the effects of exposure to violence on risk attitudes consistently finds significant effects, sometimes more than 50 years after the initial exposure (Kim and Lee, 2014). The exact effects, however, are less clear due to the considerable variation in the estimated effects. Moreover, while most studies find increased risk aversion, a prominent early study finds the opposite (Voors et al. 2012). Rockmore et al. (2016) demonstrate that the wide range of estimated effects (and even the differing signs of the estimated effect) may arise from the varying individual exposure - both types of direct exposure to violence and different responses to direct and indirect exposure. With the exception of Jakiela and Ozier $(2015)^{18}$, previous estimates reflect some population weighted

\footnotetext{
${ }^{16}$ For details on how these trends were created, see Brown (2015).

${ }^{17}$ Velásquez (2015) followed the same strategy and found similar results.

${ }^{18}$ Jakiela and Ozier (2015) study the effect of exposure to the post-election violence in Kenya. Since the vast majority of their sample only apparently suffered indirect exposure to violence, they largely measure the effect of an increase in insecurity.
} 
average of these different forms of exposure. One strength of this paper is that we are able to isolate the effects of a large increase in indirect exposure to violence (i.e. the increased insecurity) since our sample is not directly affected by the violence. ${ }^{19}$

Table 1 divides the sample into communities with above and below median homicide rates in 2009 (10.6 per 100,000 inhabitants) and compares the pre-treatment means for the control variables. With the exception of age, age squared, and household size, the characteristics for the two groups are very similar. The differences due to bordering the US are understandable since this area often forms part of the drug corridor to the US. Consequently, these are very profitable areas and vigorously contested.

We formally estimate the linear DiD using the continuous treatment variable in Table 2 (Panel A). In this and subsequent tables, we begin by just controlling for household characteristics (odd columns) before adding municipal control variables (even columns). The estimated coefficients represent the increase in risk aversion from an additional homicide (per 10,000 inhabitants) in the municipality. Our estimated coefficients are largely consistent with bulk of the micro-conflict literature that finds that exposure to violence increases risk aversion. Specifically, an increase of 1 homicide increases the likelihood of being risk averse by 1.8 to 2.0 percentage points (columns 1 and 2). This represents approximately 5 percent increase in risk aversion from the average. We find similar results, albeit with larger coefficients, in the robustness tests (columns 3-6). This is understandable since it represents exposure to a bigger 'shock'. The estimated magnitude, a 9-11 percentage point increase in the likelihood of being in the risk averse group, is qualitatively similar to Moya (2015).

\footnotetext{
${ }^{19}$ The literature on the effects of violence on social cooperation similarly combines these effects.
} 
Since the threshold for the binary outcome variable is arbitrary, we examine an alternate threshold in Panel B of Table 2 by using the second category as the new threshold for the binary variable. To verify the robustness of the baseline findings to alternative thresholds (at least qualitatively), we recode the binary variable such that the first three categories are now assigned the value of 1 in the binary conversion. The estimate coefficients are qualitatively similar to those in Panel A with slight increase in magnitudes. This suggests that our earlier results are not due to the particular transformation of the categorical outcome variable into a binary variable.

Similarly, we examine whether there is any heterogeneity based on individual characteristics. In results presented in the supplementary appendix, we find no statistically significant differences based on gender, age, or education levels.

We therefore conclude that exposure to violence at the municipality level in Mexico results in people becoming more risk averse and that this result is robust to different specifications, and change of the thresholds for the binary conversion of the risk aversion outcome variable. Moreover, there is limited heterogeneity in the effect of violence exposure on risk aversion across gender, age or education levels (Online Appendix: Table A1). These results are broadly consistent with the broader micro-conflict literature.

\subsection{Violence and Mental Health}

The literature on the effects of exposure to violence in risk aversion invariably notes the effects of the exposure on mental health. While the effects described in the mental health literature appear consistent with changes in behavioral parameters (Macksoud et al. 1993), this has only been studied twice (Moya 2015; Rockmore et al. 2016). While these studies find that mental health is an important channel, it only explains part of the subsequent changes in risk aversion (Rockmore et al. 2016). We build on these two studies by exploring the effects of violence exposure on mental 
health with two questions in mind: First, does violence affect mental health in the Mexican context? Second, if there is an effect, is this an (important) channel for explaining the increased risk aversion?

We investigate these questions in Table 3 (Panel A) and find that the estimated coefficients are statistically insignificant and close to zero. This lack of significance for the effect of violence exposure on mental health is initially surprising since this pathway implicitly (and explicitly) underlies much of the existing literature. One possibility is that this is caused by our combining moderate and severe depression into one category (to create a binary variable). We therefore reestimated the models recoding severe depression as 1 and everything else as 0 . As shown in Panel $\mathrm{B}$, the results are qualitatively similar to our earlier results. Another possibility is that mental health only responds to higher levels of violence but we find no support for this (column 3-6). Lastly, we replicate the analysis using the underlying mental health score in place of the binary depression variable and find no statistically significant effect (Appendix Table A2). ${ }^{20}$

The difference between our results and Moya (2015) or Rockmore et al. (2016) is likely due to the exposure to violence in the respective samples. The mental health literature suggests that direct (and prolonged) exposure to violence is required for substantial changes to mental health. These earlier studies focused on setting where there a large proportion of the sample was directly affected by (high levels of) violence. In contrast, as shown by our data, relatively few people are directly exposed to violence in Mexico. Since we use an aggregate measure of violence, this suggests that 'too few' people are exposed to violence and/or the average level of exposure is not sufficiently high to change mental health levels. That said, our results do suggest that while mental health may

\footnotetext{
${ }^{20} \mathrm{We}$ find no heterogeneity across gender, education and age in terms of sign, significance and magnitude. Similar effects are found using the alternate robustness tests.
} 
play an important role for changes in risk aversion, it is not a necessary condition. We find clear and robust changes to risk aversion without any corresponding changes to mental health. ${ }^{21}$ This suggests that the focus on mental health in the literature, while important, may ignore other relevant channels.

\subsection{Violence and Pro-Social Behavior}

In their recent review of the micro-conflict literature on social cooperation, Bauer et al. (2016) find a remarkably consistent effect irrespective of gender, age, or even victim vs perpetrator of violence. In particular, exposure to violence leads to 'pro-social' behavior as individuals join local groups, become more politically active and serve as local leaders. The limited available evidence suggests that this pro-social behavior is targeted towards in-groups (e.g. kinship networks, local areas) and may come at the expense of out-group cooperation. Since Bauer et al. (2016) only include 2 studies with criminal violence, they only tentatively suggest that exposure to violence may be more important than the particular type of violence (i.e. exposure to violence versus exposure to 'war'). That is, the effects of exposure to violence on social cooperation are also consistent across types of violence. ${ }^{22}$ This subsection examines this hypothesis across different types of social co-operation.

We first examine the impact of violence on private social capital (statement (ii)) in Panel A of Table 4. We note that the negative sign for the ATET means that the respondents disagree with the

\footnotetext{
${ }^{21}$ As noted earlier, an earlier version of Brown et al. (2017) investigates the related question of whether emotional well-being mediates the effects of exposure to violence on risk aversion and does not find any statistically significant effects. Their measure is based on the Short Form 36 Health Survey, a general measure of physical and mental health. Their findings are consistent with ours. We differ in that our measure of mental health (based on CES-D scale) has been validated to indicate clinical depression symptoms and provides a more direct and specific measure of that particular dimension of mental health. Irrespective, we view the results in both papers as fundamentally complementary.

${ }^{22}$ In fact, they directly reference the Mexican context as somewhere where there may be minimal difference between crime and civil conflict.
} 
statement 'No one should get involved in family or friends' problems'. The estimation results, however, are statistically insignificant. Since this differs from Bauer et al.'s (2016) review of the literature, we consider several possible explanations ${ }^{23}$. First, similar to our discussion of mental health, we consider whether these effects manifest themselves at higher levels of homicide rates using a binary treatment indicators with thresholds (column 3-6) but again find no effect. We then consider whether the effect varies by age as Bauer et al. (2013) find that exposure to violence affects in-group (egalitarian) behavior but only when individuals are exposed between ages 7 and 20 years old. Unfortunately, the youngest people in our sample are 15 so we cannot examine the full range. However, the estimated coefficient for the 15-20 year old sample (in 2009) is not significant (although it is larger in magnitude). ${ }^{24}$

Taken together, these results suggest that exposure to increased insecurity does not affect in-group social capital. This stands in sharp contrast to the micro-conflict literature where the increased private social capital potentially offsets decreased civil social capital. For example, Cassar et al. (2013) found, in the context of the Tajik civil war, that exposure to conflict resulted in a reduction in the willingness to engage in impersonal interactions while reinforcing kinship-based morality norms. Similarly, Rohner et al. (2013) that the fighting decreased generalized trust while increasing ethnic identity In Uganda. In part, this may reflect the strong in- and out-group aspects to civil conflict (e.g. ethnic identity) which are not present in the criminal violence in Mexico.

We next examine our findings for statement (i) of pro-social behavior; i.e., broader civic norms. The estimated coefficients are statistically significant in every specification (Table 4: Panel B). ${ }^{25}$ A possible explanation could be that people who experience an increase in violence perceive their

\footnotetext{
${ }^{23}$ These results are available upon request.

24 These results are available upon request.

${ }^{25} \mathrm{We}$ find some support for differences across gender.
} 
exposure as a failure of the system/institutions by the public to protect them. This loss of trust in civic institutions and, in particular, in the rule of law leads to a reduction in the desire to comply with these laws leading to lower levels of social capital (Paras 2007). Our results are generally supportive of the findings of Blanco (2012) and Blanco and Ruiz (2013) for Mexico and Columbia, respectively, who employ different $\operatorname{data}^{26}$ and find that increased perceptions of insecurity and crime victimization have negative effects on trust in institutions related to the criminal justice system.

\subsection{Migration and Attrition}

We finally address two other potential threats to identification ${ }^{27}$; i.e., migration and sample attrition. In order to address these concerns, we follow the approaches in Brown (2015) and Velásquez (2015).

\subsubsection{Migration}

Migration (e.g., out of high violence municipalities) potentially poses a threat to identification if it is driven by unobserved factors. It turns out that those respondents who migrated between the pre- and post-treatment waves represent only $3 \%$ percent of the sample. Nevertheless, we attempt to directly verify that this migration was not in response to violence. We first constructed a measure of migration by using a dummy variable to indicate whether the respondent's municipality changed between the second and third waves of the data. Using a probit model, this indicator is then regressed on the change in homicide rates between 2005 and 2009 controlling for a set of individual

\footnotetext{
${ }^{26}$ Specifically, survey data from the Latin American Public Opinion Project (LAPOP) and Encuesta Nacional Sobre la Inseguridad (ENSI).

${ }^{27}$ In results which are available upon request, we conduct standard falsification (i.e., placebo) tests for the binary treatment variables using pre-treatment data. We directly examine this for mental health. Due to a lack of data, we cannot directly examine this for risk aversion or social behavior and therefore examine on other pre-treatment variables that are correlated with risk aversion and pro-social behavior.
} 
and household characteristics and state fixed effects. The results (marginal effects) are shown in Table 5. Columns 1 and 2 of Table 5 confirm that migration is not associated with the surge in violence. The coefficients of the change in violence are not significantly different from zero indicating that the surge in violence does not predict migration.

This result is consistent with Brown (2015) for this particular measure of migration. Moreover, migration behavior does not appear to be specific to any group; the coefficients to the interaction terms between change in violence and individual and household characteristics are insignificant except for the case of married people. However, even in this latter case, the coefficient is significant at only the $10 \%$ level and the small value of the coefficient suggests a small impact on migration decision. In unreported results (available upon request), we also check that our baseline results are robust to dropping migrants from the sample and find that this is, in fact, the case.

\subsubsection{Attrition}

The attrition rate between the pre- and post-treatment samples (i.e., MxFLS2 and MxFLS3) is $23 \%$. This is certainly a substantial number. We attempt to check whether the decision to attrite from the sample was affected by the surge in violence. We define an attrition variable that takes the value 1 if the respondent was not present in the MxFLS3 wave conditional on being present in the MxFLS2 wave; 0 otherwise (Velásquez 2015). We then run a probit regression of the attrition variable on the change in homicide rates between 2005 and 2009, a set of individual and household characteristics and state fixed effects. The results (marginal effects) from the probit regression are shown in columns 3 and 4 in Table 5. The evidence suggests that attrition from the MxFLS3 is potentially not being caused by anticipation of future violence. Similar results are found in Brown (2015) and Velásquez (2015). Moreover, except for years of education, the interaction terms for change in violence and individual and household characteristics are also insignificant, suggesting 
that violence does not predict attrition within specific groups. The coefficient of the interaction term for education, although statistically significant, is also small suggesting a negligible effect on the decision to attrite from the panel.

Overall, our findings for migration and attrition suggests that the surge in violence was plausibly exogenous, and, at least across the span of the pre- and post-treatment waves of the data, individuals did not spatially sort across treatment and control municipalities nor systematically attrite from the panel because of it.

\section{CONCLUSION}

With the rise of criminal violence in many areas of the world, it is important to understand its consequences for economic behavior. Using the exogenous surge in violence caused by the crackdown on the drug trade in Mexico, we present one of the first systematic examinations of its effects in the context of Mexico and consider how these results differ from the earlier microconflict literature.

Similar to much of the literature, we find strong evidence of increased risk aversion. Insofar as we have a 'clean' measure of insecurity, our results suggest that the effects of violence need not be limited to directly affected population as indirectly exposed individuals are also affected (similar to Rockmore (2016) study of the relative per capita consumption costs of direct vs indirect exposure). We differ, however, with respect to the effects of violence exposure on mental health. Prior research focuses on mental health as the primary channel through which changes in risk aversion occur. Although we find strong effects of exposure to violence on risk aversion, we do not find a similar effect on mental health. At the very least, this result suggests that while mental health changes may be one channel for determining risk aversion, it is unlikely to be the only channel. Further research is required to identify alternate channels. 
Finally, we also investigate the effects of violence exposure on pro-social behavior. We find that exposure to violence resulted in a reduced willingness to support generalized social institutions (e.g., legal and generalized social norms). This potentially arises from the direct loss of trust due to the perceived failure of state institutions to stem violence and to protect the public from its consequences. In part, this may explain why insecurity arising from crime is linked to decreased support for democracy in Latin America and the Caribbean (Cruz, 2008). In contrast to the microconflict literature, we do not observe any concurrent strengthening of personal/kinship bonds to offset the aforementioned decrease in support. Consequently, in contrast to the micro-conflict literature, our results suggest that increased criminal violence generally lowers civic cooperation and trust.

The duration of these effects, however, is unclear. Although both the mental health (Hubbard et al. 1995; Kulka et al. 1990; McSharry and Kinny 1992; Schnurr et al. 2004) and micro-conflict (Kim and Lee 2014) literatures find that behavioral changes arising from trauma can persist for decades, these typically study direct exposure to high levels of trauma. Whether or not these effects similarly persist after exposure to insecurity is unclear. In large part, this will determine whether this friction on growth persists after the decline of the current levels of violence 


\section{References}

Algan, Y., \& Cahuc, P. (2010). Inherited trust and growth. American Economic Review, 100(5), 2060-2092.

Bateson, R. (2012). Crime victimization and political participation. American Political Science Review, 106(03), 570-587.

Bauer, M., Blattman, C., Chytilová, J., Henrich, J., Miguel, E., \& Mitts, T. (2016). Can war foster cooperation?. The Journal of Economic Perspectives, 30(3), 249-274.

Bellows, J., \& Miguel, E. (2009). War and local collective action in Sierra Leone. Journal of Public Economics, 93 (11), 1144-1157.

BenYishay, A., \& Pearlman, S. (2014). Crime and Microenterprise Growth: Evidence from Mexico. World Development. 56: 139-152.

Bertrand, M., Duflo, E. \& Mullainathan, S. (2004). How Much Should We Trust Differences-InDifferences Estimates? The Quarterly Journal of Economics, 119(1), 249-275.

Binswanger, H. P. (1980). Attitudes toward risk: Experimental measurement in rural India. American Journal of Agricultural Economics, 62, 395-407.

Blanco, L. (2012). The impact of insecurity on democracy and trust in institutions in Mexico. RAND Working Paper WR-940.

Blanco, L., \& Ruiz, I. (2013). The impact of crime and insecurity on trust in democracy and institutions. American Economic Review, 103 (3): 284-88.

Blattman, C. (2009). From violence to voting: war and political participation in Uganda. American Political Science Review, 103 (02), 231-247.

Blundell, R., \& Costa Dias, M. (2009). Alternative approaches to evaluation in empirical microeconomics. Journal of Human Resources, 44, 565-640. 
Brown, R. (2015). The Mexican drug war and early life health: The impact of violent crime on birth outcomes. Working Paper.

Brown, R., \& Velásquez, A. (2015). The effect of violent crime on the human capital accumulation of young adults. Presented at the 2015 Population Association of America Annual Meeting, San Diego, CA.

Brown, R., Thomas, D., Montalva, V., \& Velásquez, A. (2017). Impact of violent crime on risk aversion: Evidence from the Mexican drug war. National Bureau of Economic Research Working Paper No. 23181.

Calderon, G.N. (1997). Un Cuestionario para Simplicar el Diagnóstico del Síndrome Depresivo Revista de Neuro-Psiquiatría, 60, 127-135.

Calderón, G., Robles, G., \& Magaloni, B. (2013). Economic Consequences of Drug-Trafficking Violence in Mexico (No. IDB-WP-426). Inter-American Development Bank, Research Department.

Callen, M., Isaqzadeh, M., Long, J. D., \& Sprenger, C. (2014). Violence and risk preference: Experimental evidence from Afghanistan. American Economic Review, 104 (1), 123-48.

Cameron, L., \& Shah, M. (2013). Risk-taking behavior in the wake of natural disasters. NBER Working Paper 19534, National Bureau of Economic Research.

Cassar, A., Grosjean, P., \& Whitt, S. (2013). Legacies of violence: Trust and market development. Journal of Economic Growth, 18 (3), 285-318.

Cilliers, J., Dube, O., Siddiqi, B. (2016). Reconciling after civil conflict increases social capital but decreases individual well-being. Science. 13; 352(6287):787-94 
Croson, R. \& Gneezy, U. (2009). Gender differences in preferences. Journal of Economic Literature, 47 (2), 448-474

Cruz-Coke, M. L. (2008). Latin America's diversity of views. Journal of Democracy, 19(1), 111125.

Dasgupta, P. (2005). The economics of social capital. The Economic Record, 81 (special issue), S2- S21.

De Luca, G., \& Verpoorten, M. (2015). Civil war, social capital and resilience in Uganda. Oxford Economic Papers, 67(3), 661-686.

Dohmen, T., Falk A., Huffman D., Sunde U., Schupp, J. \& Wagner, G. G. (2005). Individual risk attitudes: New evidence from a large, representative, experimentally-validated survey. Discussion Paper No. 1730, DIW Berlin, German Institute for Economic Research.

Durlauf, S., \& Fafchamps, M. (2004). Social capital. In S. Durlauf \& P. Aghion (Eds.), Handbook of economic growth (1639-1700). Amsterdam: North Holland.

Eckel, C., \& Grossman, P. (2008). Forecasting risk attitudes: An experimental study using actual and forecast sample choices. Journal of Economic Behavior \& Organization, 68, 1-17.

Eckel, C. C., El-Gamal, M. A., \& Wilson, R. K. (2009). Risk loving after the storm: A Bayesiannetwork study of Hurricane Katrina Evacuees, Journal of Economic Behavior \& Organization, 69(2), 110-124.

Fafchamps, M. (2006). Development and social capital. Journal of Development Studies, 42 (7), $1180-1198$.

Guerrero-Gutiérrez, E. (2011). Security, drugs, and violence in Mexico: A survey, 7th North American Forum, Washington D.C.

Guerrero-Gutiérrez, E. (2012). Epidemias de violencia. Nexos, July (2012). 
Hamoudi, A., \& Thomas, D. (2006). Do you care? Altruism and inter-generational exchanges in Mexico, California Center for Population Research Working Paper CCPR-008-06.

Henrich, J., Ensminger, J., McElreath, R., Barr, A., Barrett, C., Bolyanatz, A.. (2010). Markets, religion, community size, and the evolution of fairness and punishment. Science, 327(5972), 14801484.

Holt, C. A., \& Laury, S. K. (2002). Risk aversion and incentive effects. The American Economic Review, 92, 1644-1655.

Hryshko, D., Luengo-Prado, M. J., \& Sorensen, B. E. (2011). Childhood determinants of risk aversion: The long shadow of compulsory education. Quantitative Economics, 2 (1), 37-72.

Hubbard, J., Realmuto, G. M., Northwood, A. K., \& Masten, A. S. (1995). Comorbidity of psychiatric diagnoses with posttraumatic stress disorder in survivors of childhood trauma. Journal of the American Academy of Child and Adolescent Psychiatry, 34 (9), 1167-1173.

Instituto Nacional de Estadística, Geografía e Informática. (2003). Síntesis metodológica de las estadísticas vitales. Mexico: INEGI.

Jakiela, P., \& Ozier, O. (2015). The impact of violence on risk preferences: Evidence from a natural experiment. Policy Research Working Paper 7440, World Bank.

Jung, S. (2015). Does education affect risk aversion? Evidence from the British education reform Applied Economics, 47 (28), 2924-2938.

Kan, P. R. (2012). Cartels at war: Mexico's drug-fueled violence and the threat to the U.S. national security. $1^{\text {st }}$ edition. Potomac Books, Washington D.C.

Kim, Y-II., \& Lee, J. (2014). The long-run impact of a traumatic experience on risk aversion. Journal of Economic Behavior and Organization, 108, 174-186. 
Knack, S., \& Keefer, P. (1997). Does social capital have an economic payoff? A cross-country investigation. Quarterly Journal of Economics, 112(4), 1251-1288.

Kulka, R. A., Schlenger, W. E., Fairbanks, J. A., Hough, R. L., Jordan, B. K., Marmar, C. R., Weiss, D. S., Grady, D. A., \& Senator Cranston, A. (1990). Trauma and the Vietnam War generation: Report of findings from the National Vietnam Veterans Readjustment Study. Brunner/Mazel Publishers. New York.

Lechner, M. (2011). The estimation of causal effects by difference-in-difference methods. Discussion paper, Economics Department, University of St. Gallen.

Macksoud, M. S., Dyregrov, A., \& Raundalen, M. (1993) Traumatic war experiences and their effects on children in International Handbook of Traumatic Stress Syndromes, ed. John P. Wilson and Beverley Raphael, Plenum Press. New York and London.

Malmendier, U., \& Nagel, S. (2011). Depression babies: Do macroeconomic experiences affect risk-taking? Quarterly Journal of Economics, 126(1), 373-416.

Manian, S. (2015). Risk vulnerability and health behavior: Evidence from Mexico's drug war. Presented at NEUDC 2015, Brown University.

Mather, M., Nina M., Marissa, A. G., Nichole, R. L., Jessica, B., Andrej, S., \& Dan, A. (2012). Risk preferences and aging: The "Certainty Effect" in older adults' decision making. Psychology and Aging, 27, 801-816.

McSharry, S., \& Kinney, R. (1992). Prevalence of psychiatric disorders in Cambodian refugees: A community random sample. Unpublished Manuscript. Social Research Institute, Graduate School of Social Work, University of Utah, Salt Lake City, Utah. 
Molzahn, C., Rios V., \& Shirk, D. (2012). Drug violence in Mexico: Data and analysis through 2011. Trans-Border Institute, Kroc School of Peace Studies at the University of San Diego, Special Report.

Morrison, Kevin M., \& Marc Rockmore (2016). Fear and Political Participation: Evidence from Africa. Households in Conflict Network Working Paper No. 226.

Moya, A. (2015). Violence, mental trauma, and induced changes in risk attitudes among the internally displaced population in Colombia. Working Paper.

Nunn, N., \& Wantchekon, L. (2011). The slave trade and the origins of mistrust in Africa. The American Economic Review, 101(7), 3221-3252.

Paras, P. (2007). Unweaving the social fabric: the impact of crime on social capital. In Cornelius, Wayne A., and David A. Shirk (Eds). Reforming the administration of justice in Mexico. Notre Dame, Ind: University of Notre Dame Press.

Putnam, R. (2000) Bowling Alone: The Collapse and Revival of the American Community New York: Simon \& Schuster.

Radloff, L. S. (1977). The CES-D Scale. Applied Psychological Measurement, 1 (3), 385-401.

Rios, V. (2015). How Government Coordination Controlled Organized Crime: The Case of Mexico’s Cocaine Markets. Journal of Conflict Resolution, 59(8), 1433-1454.

Rockmore, M. (2016) The Cost of Fear: The Welfare Effect of the Risk of Violence in Northern Uganda. World Bank Economic Review, forthcoming, http://dx.doi.org/10.1093/wber/lhw025.

Rockmore, M., Barrett, C. B., \& Annan, J. (2016). An Empirical Exploration of the Near-Term and Persistent Effects of Conflict on Risk Preferences Households in Conflict Network Working Paper No. 239. 
Rohner, D., Thoenig, M., \& Zilibotti, F. (2013). Seeds of distrust: Conflict in Uganda. Journal of Economic Growth, 18 (3), 217-252.

Rojo-Mendoza, R. T. (2014). From Victims to Activists: Crime Victimization, Social Support, and Political Participation in Mexico.. Unpublished paper.

Rubalcava, L., \& Teruel, G. (2013). Mexican family life survey, Third wave. Working Paper, www.ennvih-mxfls.org.

Schnurr, P. P., Lunney, C. A., \& Sengupta, A. (2004). Risk factors for the development versus maintenance of posttraumatic stress disorder. Journal of Traumatic Stress, 17(2):85-95.

Silva, A., Mace, R. (2014). Cooperation and Conflict: Field Experiments in Northern Ireland. Proceedings of the Royal Society B Biological Studies. 281 (1792).

Skriabikova, O. J., Dohmen, T., \& Kriechel B. (2014). New evidence on the relationship between risk attitudes and self-employment. Labour Economics, 30, 176-184.

Steffick, D. (2000). HRS/AHEAD documentation report DR-005. Survey Research Center, University of Michigan; Ann Arbor, MI. Documentations of affective functioning measures in the Health and Retirement Study.

Stigler, G. J., \& Becker, G. S. (1977). De gustibus non est disputandum. American Economic Review, 67 (2), 76-90.

United Nations. (2011). Feminicidio en México. Aproximación, tendencias y cambios, 1985-2009. ONU Mujeres, Entidad de las Naciones Unidas para la igualdad de Gnero y el Empoderamiento de las Mujeres

Velásquez, A. (2015). The economic burden of crime: Evidence from Mexico. Working Paper. 
Voors, M. J., Eleonora, E. M. N., Philip, V., Erwin, H. B., Robert, L., \& Daan, P. V. S. (2012). Violent conflict and behavior: A field experiment in Burundi. American Economic Review, 102 (2), 941-64.

World Bank (2011). World Development Report 2011: Conflict, Security, and Development. World Bank. https://openknowledge.worldbank.org/handle/10986/4389 License: CC BY 3.0 IGO. Zak, P., \& Knack, S. (2001). Trust and growth. Economic Journal, 111, 295-321. 


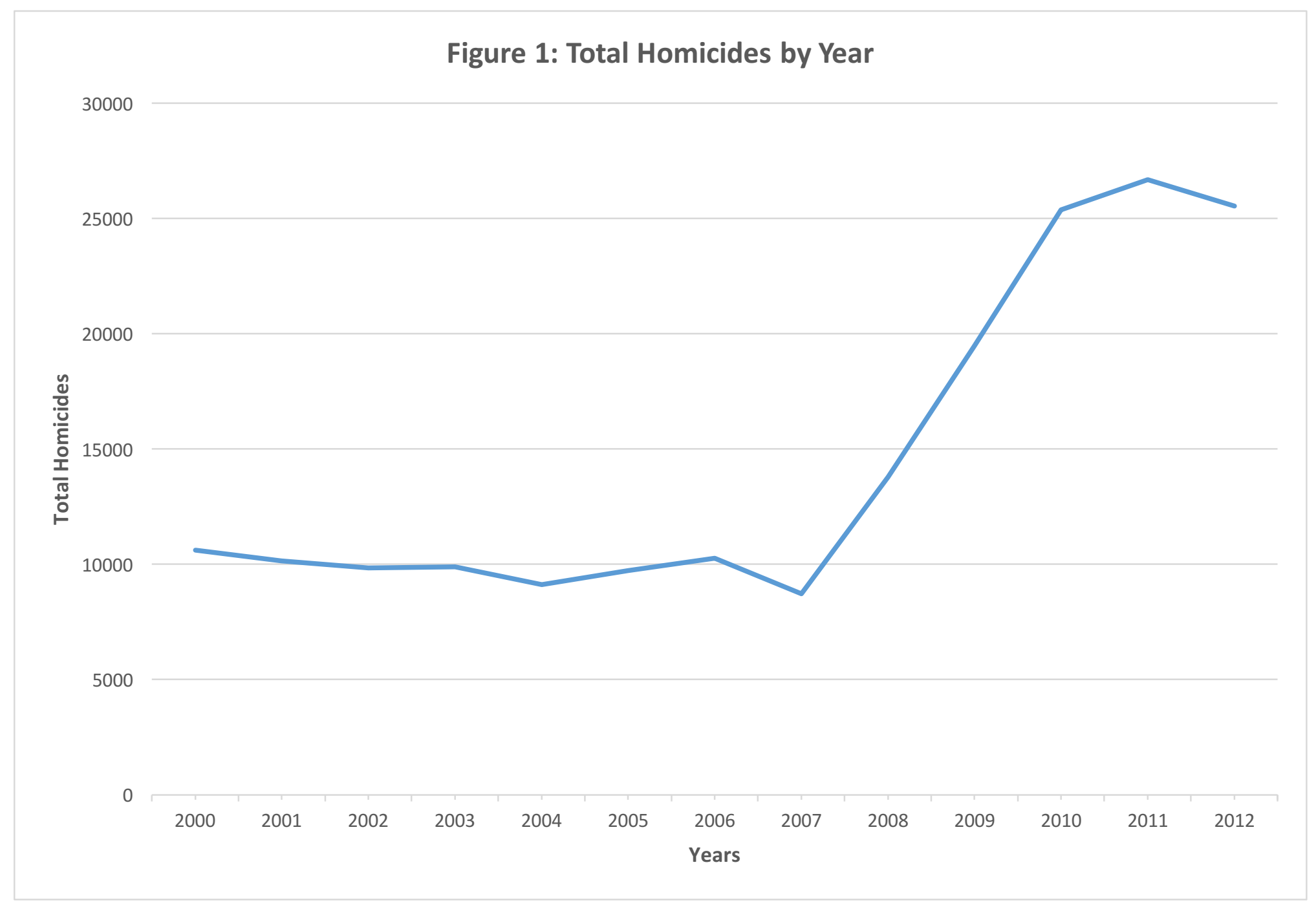

Source: Authors' calculations using INEGI data 

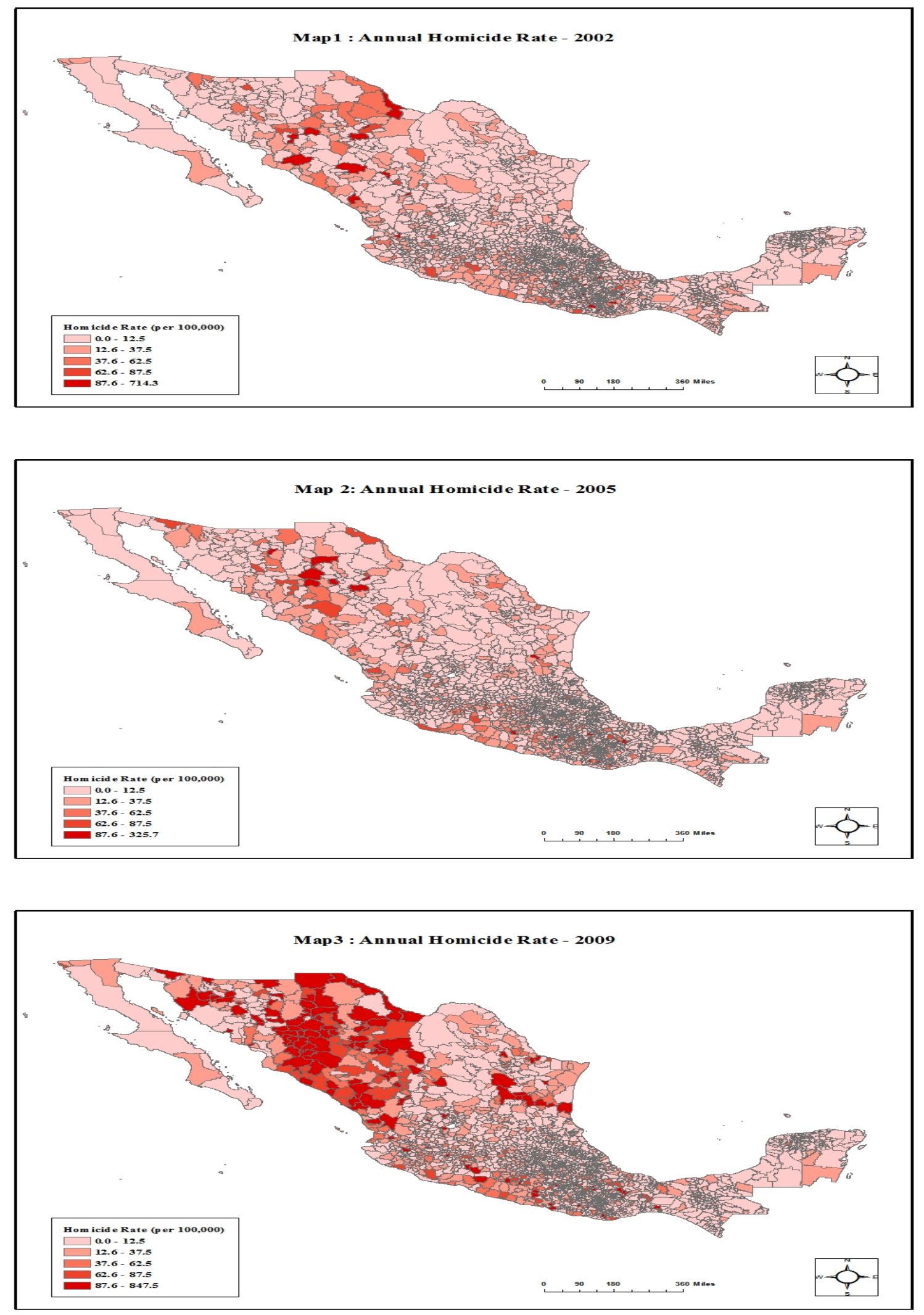

Source: Authors' calculations using INEGI data 
Table 1: Descriptive Statistics

Treated Group Control Group Difference

\begin{tabular}{|c|c|c|c|}
\hline Individual Characteristics & & & \\
\hline \multirow[t]{2}{*}{ Age } & 38.46 & 37.46 & $1.0068^{*}$ \\
\hline & $(0.400)$ & $(0.355)$ & $(0.532)$ \\
\hline \multirow[t]{2}{*}{ Age Squared } & 1764.3 & 1671.7 & $92.61 *$ \\
\hline & $(36.00)$ & $(31.50)$ & $(47.67)$ \\
\hline \multirow[t]{2}{*}{ Gender } & 0.406 & 0.411 & -0.004 \\
\hline & $(0.007)$ & $(0.006)$ & $(0.010)$ \\
\hline \multirow[t]{2}{*}{ Education } & 7.350 & 7.192 & 0.157 \\
\hline & $(0.203)$ & $(0.224)$ & $(0.302)$ \\
\hline \multirow[t]{2}{*}{ Marriage } & 0.525 & 0.544 & -0.018 \\
\hline & $(0.012)$ & $(0.012)$ & $(0.018)$ \\
\hline \multirow[t]{2}{*}{ Employment } & 0.481 & 0.491 & -0.009 \\
\hline & $(0.009)$ & $(0.010)$ & $(0.014)$ \\
\hline \multicolumn{4}{|l|}{ Household Characteristics } \\
\hline \multirow[t]{2}{*}{ Household Size } & 5.137 & 5.460 & $-0.323 * *$ \\
\hline & $(0.094)$ & $(0.120)$ & $(0.153)$ \\
\hline \multirow[t]{2}{*}{ Household Expenditure } & 67352 & 69146 & -1794 \\
\hline & $(3283)$ & (4934) & $(5910)$ \\
\hline \multirow[t]{2}{*}{ Household Wealth } & 0.843 & 0.843 & 0.000 \\
\hline & $(0.015)$ & $(0.012)$ & $(0.019)$ \\
\hline \multicolumn{4}{|l|}{ Municipality Characteristics } \\
\hline \multirow[t]{2}{*}{ Border with US } & 0.208 & 0.143 & $0.065 * * *$ \\
\hline & $(0.082)$ & $(0.065)$ & $(0.105)$ \\
\hline \multirow[t]{2}{*}{ Agriculture Production Area } & 40641 & 15332 & 25309 \\
\hline & (15024) & $(3702)$ & $(15440)$ \\
\hline \multirow[t]{2}{*}{ Housing (total private dwelling) } & 65698 & 70143 & -4444 \\
\hline & $(13886)$ & $(15398)$ & $(20672)$ \\
\hline \multirow[t]{2}{*}{ Average Household Size } & 4.113 & 4.206 & -0.093 \\
\hline & $(0.031)$ & $(0.060))$ & $(0.068)$ \\
\hline \multirow[t]{2}{*}{ Conviction Rate } & 86.15 & 85.65 & 0.492 \\
\hline & $(1.772)$ & $(2.232)$ & $(2.842)$ \\
\hline \multirow[t]{2}{*}{ Literacy Rate } & 86.16 & 86.11 & 0.045 \\
\hline & $(0.218)$ & $(0.273)$ & $(0.347)$ \\
\hline \multirow[t]{2}{*}{ Health Care Access } & 46.04 & 51.34 & -5.299 \\
\hline & $(3.064)$ & $(2.451)$ & $(3.908)$ \\
\hline Observations & 4274 & 4376 & \\
\hline
\end{tabular}

Note: $* * * * *$ and $*$ show significance at $1 \%, 5 \%$ and $10 \%$ levels respectively. Robust standard errors, clustered at the municipality level, are reported in parenthesis. Household wealth is measured by whether or not the respondent owns a house. All the characteristics are from pre-escalation period (2005-06 survey). 
Table 2: Risk Aversion

\begin{tabular}{|c|c|c|c|c|c|c|}
\hline & \multicolumn{2}{|c|}{ Continuous Treatment } & \multicolumn{2}{|c|}{ Binary (Median) } & \multicolumn{2}{|c|}{ Binary (3 ${ }^{\text {rd }}$ Quartile) } \\
\hline Variable & 1 & 2 & 3 & 4 & 5 & 6 \\
\hline \multicolumn{7}{|c|}{ Panel A: Main Results } \\
\hline ATET & $\begin{array}{c}0.020^{* * *} \\
(0.005)\end{array}$ & $\begin{array}{c}0.018^{* * * *} \\
(0.005)\end{array}$ & $\begin{array}{c}0.112 * * * \\
(0.030)\end{array}$ & $\begin{array}{c}0.108^{* * *} \\
(0.030)\end{array}$ & $\begin{array}{c}0.102 * * \\
(0.040)\end{array}$ & $\begin{array}{c}0.096^{* *} \\
(0.040)\end{array}$ \\
\hline \multicolumn{7}{|c|}{ Panel B: Robustness (Binary Conversion) } \\
\hline ATET & $\begin{array}{c}0.026^{* * *} * \\
(0.005)\end{array}$ & $\begin{array}{c}0.024^{* * *} * \\
(0.005)\end{array}$ & $\begin{array}{c}0.130^{* * *} \\
(0.028)\end{array}$ & $\begin{array}{c}0.126^{* * *} \\
(0.029)\end{array}$ & $\begin{array}{c}0.140 * * * \\
(0.033)\end{array}$ & $\begin{array}{c}0.136^{* * *} \\
(0.034)\end{array}$ \\
\hline $\begin{array}{c}\text { Household Ch. } \\
\text { Municipality } \mathrm{Ch} . \\
\text { Observations }\end{array}$ & $\begin{array}{c}\text { Yes } \\
\text { No } \\
17294 \\
\end{array}$ & $\begin{array}{c}\text { Yes } \\
\text { Yes } \\
17294\end{array}$ & $\begin{array}{c}\text { Yes } \\
\text { No } \\
17294 \\
\end{array}$ & $\begin{array}{c}\text { Yes } \\
\text { Yes } \\
17294\end{array}$ & $\begin{array}{c}\text { Yes } \\
\text { No } \\
17294 \\
\end{array}$ & $\begin{array}{c}\text { Yes } \\
\text { Yes } \\
17294 \\
\end{array}$ \\
\hline
\end{tabular}

Note: $* * *$ and $* *$ show significance at $1 \%$ and $5 \%$ levels respectively. Bootstrap standard errors, clustered at municipality level, are shown in parenthesis. The individual level control variables include age, age square, gender, education, marital status, employment status, household size, household expenditure and wealth. The municipality characteristics include municipality level literacy rate, access to health services, total number of private dwellings, number of persons per dwelling, conviction rate and an indicator for whether the municipality is along the US border or touches the route to the US. 
Table 3: Mental Health

\begin{tabular}{|c|c|c|c|c|c|c|}
\hline & \multicolumn{2}{|c|}{ Continuous Treatment } & \multicolumn{2}{|c|}{ Binary (Median) } & \multicolumn{2}{|c|}{ Binary (3 ${ }^{\text {rd }}$ Quartile $)$} \\
\hline Variable & 1 & 2 & 3 & 4 & 5 & 6 \\
\hline \multicolumn{7}{|c|}{ Panel A: Main Results } \\
\hline ATET & $\begin{array}{c}-0.0003 \\
(0.001)\end{array}$ & $\begin{array}{l}0.0002 \\
(0.001)\end{array}$ & $\begin{array}{l}-0.008 \\
(0.006)\end{array}$ & $\begin{array}{l}-0.007 \\
(0.006)\end{array}$ & $\begin{array}{c}0.002 \\
(0.006)\end{array}$ & $\begin{array}{c}0.003 \\
(0.006)\end{array}$ \\
\hline
\end{tabular}

Panel B: Robustness ( Binary Conversion)

$\begin{array}{lllllll} & -0.001 & -0.0008 & -0.0001 & -0.0001 & -0.004 & -0.003 \\ \text { ATET } & (0.001) & (0.001) & (0.000) & (0.000) & (0.003) & (0.002)\end{array}$

$\begin{array}{ccccccc}\text { Household Ch. } & \text { Yes } & \text { Yes } & \text { Yes } & \text { Yes } & \text { Yes } & \text { Yes } \\ \text { Municipality Ch. } & \text { No } & \text { Yes } & \text { No } & \text { Yes } & \text { No } & \text { Yes } \\ \text { Observations } & 17294 & 17294 & 17294 & 17294 & 17294 & 17294\end{array}$

Note: Bootstrap standard errors, clustered at municipality level, are shown in parenthesis. The individual level control variables include age, age square, gender, education, marital status, employment status, household size, household expenditure and wealth. The municipality characteristics include municipality level literacy rate, access to health services, total number of private dwellings, number of persons per dwelling, conviction rate and an indicator for whether the municipality is along the US border or touches the route to the US. 
Table 4: Pro-Social Behavior

\begin{tabular}{|c|c|c|c|c|c|c|}
\hline & \multicolumn{2}{|c|}{ Continuous Treatment } & \multicolumn{2}{|c|}{ Binary (Median) } & \multicolumn{2}{|c|}{ Binary $\left(3^{\text {rd }}\right.$ Quartile $)$} \\
\hline Variable & 1 & 2 & 3 & 4 & 5 & 6 \\
\hline \multicolumn{7}{|c|}{ Panel A: Private Social Capital - Main Results } \\
\hline ATET & $\begin{array}{l}-0.002 \\
(0.005)\end{array}$ & $\begin{array}{l}-0.002 \\
(0.005)\end{array}$ & $\begin{array}{l}-0.015 \\
(0.029)\end{array}$ & $\begin{array}{l}-0.013 \\
(0.029)\end{array}$ & $\begin{array}{c}0.006 \\
(0.029)\end{array}$ & $\begin{array}{c}0.004 \\
(0.029)\end{array}$ \\
\hline
\end{tabular}

Panel B: Broader Civic Norms - Main Results

\begin{tabular}{ccccccc}
\hline & $0.010^{* * *}$ & $0.010^{* * *}$ & $0.046^{* *}$ & $0.050^{* *}$ & $0.044^{*}$ & $0.047^{* *}$ \\
ATET & $(0.003)$ & $(0.003)$ & $(0.021)$ & $(0.021)$ & $(0.024)$ & $(0.024)$ \\
& & & & & & Yes \\
Household Ch. & Yes & Yes & Yes & Yes & Yes \\
Municipality Ch. & No & Yes & No & Yes & No & Yes \\
Observations & 16021 & 16021 & 16021 & 16021 & 16021 & 16021 \\
\hline
\end{tabular}

Note: $* * *, * *$ and $*$ show significance at $1 \%, 5 \%$ and $10 \%$ levels respectively. Bootstrap standard errors, clustered at municipality level, are shown in parenthesis. The individual level control variables include age, age square, gender, education, marital status, employment status, household size, household expenditure and wealth. The municipality characteristics include municipality level literacy rate, access to health services, total number of private dwellings, number of persons per dwelling, conviction rate and an indicator for whether the municipality is along the US border or touches the route to the US. 
Table 5: Migration and Attrition between MxFLS2 and MxFLS3

\begin{tabular}{|c|c|c|c|c|}
\hline \multirow{3}{*}{$\Delta$ Homicide Rate (2009-05) } & \multicolumn{2}{|c|}{ Migration } & \multicolumn{2}{|c|}{ Attrition } \\
\hline & (1) & (2) & (3) & (4) \\
\hline & $\begin{array}{c}0.0002 \\
(0.0002)\end{array}$ & $\begin{array}{l}-0.0013 \\
(0.0010)\end{array}$ & $\begin{array}{c}0.0001 \\
(0.0002)\end{array}$ & $\begin{array}{c}0.0004 \\
(0.0008)\end{array}$ \\
\hline$\Delta$ Homicide Rate (2009-05) ir & with $M x F$ & & & \\
\hline Age & & $\begin{array}{l}-0.0001 \\
(0.0000)\end{array}$ & & $\begin{array}{l}-0.0001 \\
(0.0000)\end{array}$ \\
\hline Age Square & & $\begin{array}{l}-0.0000 \\
(0.0000)\end{array}$ & & $\begin{array}{l}-0.0000 \\
(0.0000)\end{array}$ \\
\hline Gender & & $\begin{array}{c}0.0001 \\
(0.0002)\end{array}$ & & $\begin{array}{c}0.0002 \\
(0.0003)\end{array}$ \\
\hline Education & & $\begin{array}{l}-0.0000 \\
(0.0000)\end{array}$ & & $\begin{array}{c}0.00008 * * \\
(0.00004)\end{array}$ \\
\hline Married & & $\begin{array}{c}0.0006^{*} \\
(0.0003)\end{array}$ & & $\begin{array}{l}-0.0004 \\
(0.0003)\end{array}$ \\
\hline Employment & & $\begin{array}{c}0.0002 \\
(0.0002)\end{array}$ & & $\begin{array}{c}0.0002 \\
(0.0003)\end{array}$ \\
\hline Household Size & & $\begin{array}{c}0.0001 \\
(0.0001)\end{array}$ & & $\begin{array}{l}-0.0000 \\
(0.0000)\end{array}$ \\
\hline Household Expenditure & & $\begin{array}{c}0.0000 \\
(0.0000)\end{array}$ & & $\begin{array}{c}0.0000 \\
(0.0000)\end{array}$ \\
\hline Household Wealth & & $\begin{array}{l}-0.0002 \\
(0.0004)\end{array}$ & & $\begin{array}{l}-0.0001 \\
(0.0003)\end{array}$ \\
\hline Observations & 10,410 & 9,997 & 19,769 & 19,769 \\
\hline Mean of Dependent Variable & $3.10 \%$ & $3.23 \%$ & $22.99 \%$ & $22.99 \%$ \\
\hline State FE & No & Yes & No & Yes \\
\hline
\end{tabular}

Note: Standard errors are clustered at municipality level. ${ }^{* *}$ and $*$ show significance at $5 \%$ and $10 \%$ levels respectively. The homicide rates are per 100,000. Probit model is used for regressions. The coefficients reported in the table are marginal effects. 


\section{ONLINE APPENDIX}

Figure A1: Choice over Hypothetical Games (MxFLS2)

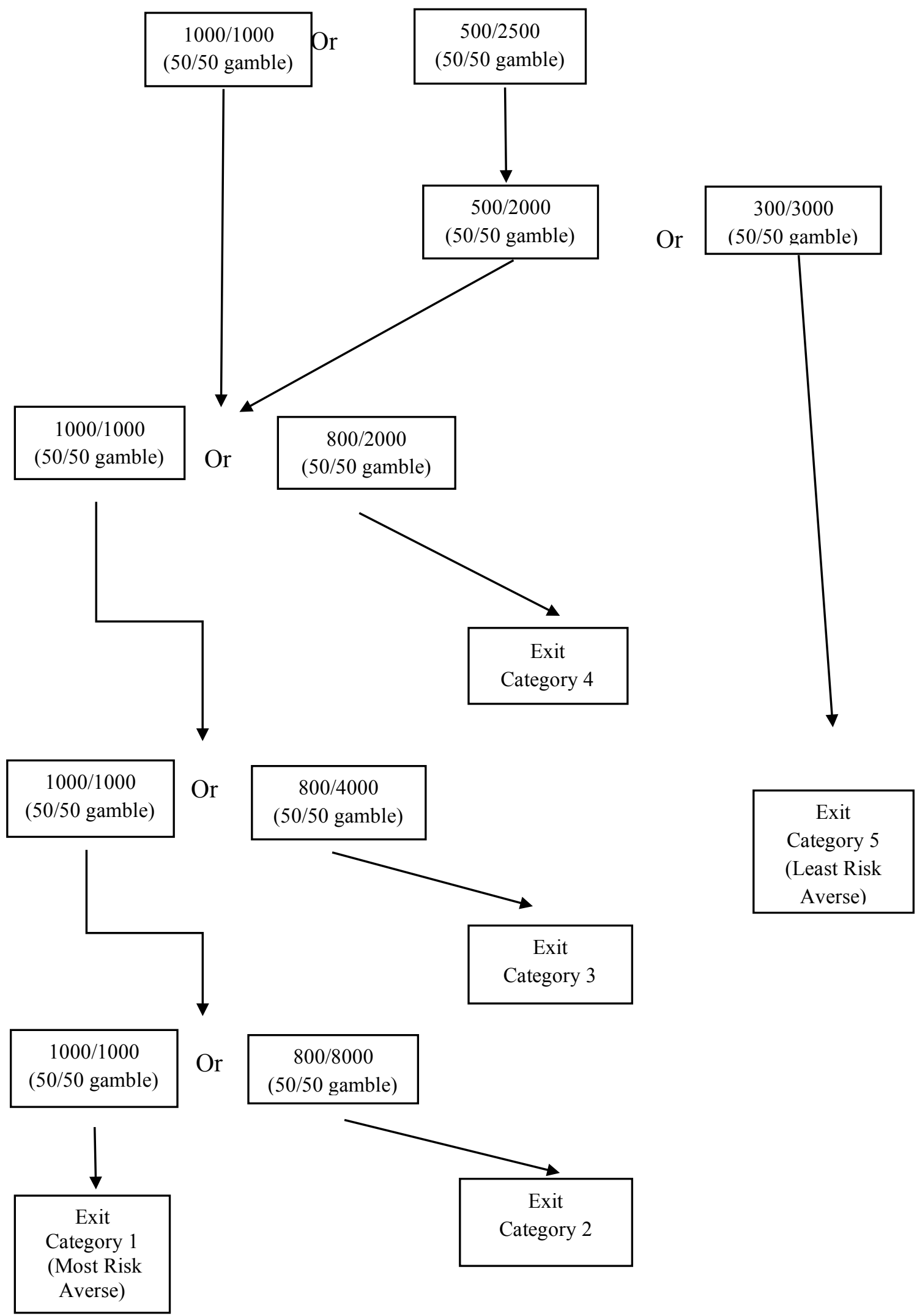




\section{Online Appendix}

Table A1: Heterogeneous Effects for Risk Aversion

\begin{tabular}{|c|c|c|c|c|c|c|c|c|c|}
\hline \multirow{2}{*}{$\begin{array}{c}\text { Variable } \\
\text { Panel } A: \text { Gender }\end{array}$} & \multicolumn{3}{|c|}{ Continuous Treatment } & \multicolumn{3}{|c|}{ Binary (Median) } & \multicolumn{3}{|c|}{ Binary (3 ${ }^{\text {rd }}$ Quartile) } \\
\hline & & & & & & & & & \\
\hline & Total & Male & Female & Total & Male & Female & Total & Male & Female \\
\hline & $0.018 * * *$ & $0.021 * * *$ & $0.016 * * *$ & $0.108 * * *$ & $0.125 * * *$ & $0.097 * * *$ & $0.096^{* *}$ & $0.142 * * *$ & 0.068 \\
\hline ATET & $(0.005)$ & $(0.007)$ & $(0.005)$ & $(0.030)$ & $(0.036)$ & $(0.030)$ & $(0.040)$ & $(0.042)$ & $(0.043)$ \\
\hline Observations & 17294 & 6696 & 10598 & 17294 & 6696 & 10598 & 17294 & 6696 & 10598 \\
\hline \multicolumn{10}{|c|}{ Panel B: Education } \\
\hline & Total & $<9$ Yrs. & $\geq 9$ Yrs. & Total & <9 Yrs. & $\geq 9$ Yrs. & Total & $<9$ Yrs. & $\geq 9$ Yrs. \\
\hline & $0.018 * * *$ & $0.016^{* * *}$ & $0.022 * * *$ & $0.108^{* * *}$ & $0.091 * * *$ & $0.129 * * *$ & $0.096^{* *}$ & $0.097 * *$ & $0.089^{*}$ \\
\hline ATET & $(0.005)$ & $(0.006)$ & $(0.006)$ & $(0.030)$ & $(0.035)$ & $(0.032)$ & $(0.040)$ & $(0.043)$ & $(0.046)$ \\
\hline Observations & 17294 & 10136 & 7158 & 17294 & 10136 & 7158 & 17294 & 10136 & 7158 \\
\hline \multicolumn{10}{|l|}{ Panel C: Age } \\
\hline & Total & $\leq 39$ Yrs. & $>39$ Yrs. & Total & $\leq 39$ Yrs. & $>39$ Yrs. & Total & $\leq 39$ Yrs. & $>39$ Yrs. \\
\hline & $0.018 * * *$ & $0.014^{* * *}$ & $0.024 * * *$ & $0.108 * * *$ & $0.097 * * *$ & $0.121 * * *$ & $0.096^{* *}$ & 0.049 & $0.150 * * *$ \\
\hline ATET & $(0.005)$ & $(0.005)$ & $(0.006)$ & $(0.030)$ & $(0.034)$ & $(0.033)$ & $(0.040)$ & $(0.045)$ & $(0.040)$ \\
\hline Observations & 17294 & 9424 & 7870 & 17294 & 9424 & 7870 & 17294 & 9424 & 7870 \\
\hline Household Ch. & Yes & Yes & Yes & Yes & Yes & Yes & Yes & Yes & Yes \\
\hline Municipality Ch. & Yes & Yes & Yes & Yes & Yes & Yes & Yes & Yes & Yes \\
\hline
\end{tabular}

Note: ${ }^{* * *}, * *$ and $*$ show significance at $1 \%, 5 \%$ and $10 \%$ levels respectively. Bootstrap standard errors, clustered at municipality level, are shown in parenthesis.

The individual and municipality level controls are the same used in main regressions. 
Table A2: Mental Health Results using Continuous Variable

\begin{tabular}{ccc}
\hline Variable & Model 1 & Model 2 \\
\hline Panel A: Main Results & & -0.176 \\
ATET & -0.271 & $(0.467)$
\end{tabular}

Panel B: Robustness (Treatment Assignment)

\begin{tabular}{|c|c|c|c|c|c|c|}
\hline ATET & & $\begin{array}{l}-0.045 \\
(0.514)\end{array}$ & & & $\begin{array}{c}0.038 \\
(0.506)\end{array}$ & \\
\hline Observations & & 17294 & & & 17294 & \\
\hline Household Ch. & & Yes & & & Yes & \\
\hline Municipality $\mathrm{Ch}$. & & No & & & Yes & \\
\hline \multicolumn{7}{|c|}{ Panel C: Heterogeneous Effects } \\
\hline \multicolumn{7}{|l|}{ I. Gender } \\
\hline & Total & Male & Female & Total & Male & Female \\
\hline & -0.271 & -0.382 & -0.211 & -0.176 & -0.301 & -0.114 \\
\hline ATET & $(0.464)$ & $(0.455)$ & $(0.530)$ & $(0.467)$ & $(0.458)$ & $(0.531)$ \\
\hline Observations & 17294 & 6696 & 10598 & 17294 & 6696 & 10598 \\
\hline \multicolumn{7}{|l|}{ II. Education } \\
\hline & Total & <9 Yrs. & $\geq 9$ Yrs. & Total & <9 Yrs. & $\geq 9$ Yrs. \\
\hline ATET & $\begin{array}{c}-0.271 \\
(0.464)\end{array}$ & $\begin{array}{l}-0.310 \\
(0.545)\end{array}$ & $\begin{array}{l}-0.168 \\
(0.494)\end{array}$ & $\begin{array}{c}-0.176 \\
(0.467)\end{array}$ & $\begin{array}{l}-0.209 \\
(0.536)\end{array}$ & $\begin{array}{c}-0.054 \\
(0.507)\end{array}$ \\
\hline Observations & 17294 & 10136 & 7158 & 17294 & 10136 & 7158 \\
\hline \multicolumn{7}{|l|}{ III. Age } \\
\hline & Total & $\leq 39$ Yrs. & > 39 Yrs. & Total & $\leq 39$ Yrs. & > 39 Yrs. \\
\hline ATET & $\begin{array}{c}-0.271 \\
(0.464)\end{array}$ & $\begin{array}{c}-0.217 \\
(0.465)\end{array}$ & $\begin{array}{l}-0.260 \\
(0.590)\end{array}$ & $\begin{array}{l}-0.176 \\
(0.467)\end{array}$ & $\begin{array}{c}-0.088 \\
(0.470)\end{array}$ & $\begin{array}{l}-0.210 \\
(0.588)\end{array}$ \\
\hline Observations & 17294 & 9424 & 7870 & 17294 & 9424 & 7870 \\
\hline Household Ch. & Yes & Yes & Yes & Yes & Yes & Yes \\
\hline Municipality Ch. & No & No & No & Yes & Yes & Yes \\
\hline
\end{tabular}

Note: Bootstrap standard errors, clustered at municipality level, are shown in parenthesis. The individual and municipality level controls are the same used in main regressions. Panel A shows the results when the treatment was defined as exposure to above median violence. Panel B checks the robustness by changing the treatment assignment to municipalities who have experienced above $75^{\text {th }}$ percentile violence. Panel $\mathrm{C}$ provides the heterogeneity analysis across gender, education and age.

Table A3: Heterogeneous Effects for Pro-Social Behavior - Broader Civic Norms

\begin{tabular}{|c|c|c|c|c|c|c|c|c|c|}
\hline \multirow{3}{*}{$\begin{array}{c}\text { Variable } \\
\text { Panel } A: G 6\end{array}$} & \multicolumn{3}{|c|}{ Continuous Treatment } & \multicolumn{3}{|c|}{ Binary (Median) } & \multicolumn{3}{|c|}{ Binary (3 ${ }^{\text {rd }}$ Quartile) } \\
\hline & ider & & & & & & & & \\
\hline & Total & Male & Female & Total & Male & $\begin{array}{c}\text { Femal } \\
\text { e }\end{array}$ & Total & Male & $\begin{array}{c}\text { Femal } \\
\text { e }\end{array}$ \\
\hline ATET & $\begin{array}{c}0.010 * * \\
* \\
(0.003)\end{array}$ & $\begin{array}{c}0.013 * * \\
* \\
(0.005)\end{array}$ & $\begin{array}{c}0.007 * \\
(0.004)\end{array}$ & $\begin{array}{c}0.050^{*} \\
*\end{array}$ & $\begin{array}{c}0.077^{* *} \\
* \\
(0.026)\end{array}$ & $\begin{array}{c}0.031 \\
(0.026 \\
)\end{array}$ & $\begin{array}{c}0.047 * \\
*\end{array}$ & $\begin{array}{c}0.097 * * \\
* \\
(0.026)\end{array}$ & $\begin{array}{c}0.013 \\
(0.030 \\
)\end{array}$ \\
\hline
\end{tabular}




\begin{tabular}{|c|c|c|c|c|c|c|c|c|c|}
\hline \multirow[b]{2}{*}{$\begin{array}{c}\text { Observatio } \\
\text { ns }\end{array}$} & \multirow[b]{2}{*}{16021} & \multirow[b]{2}{*}{6306} & \multirow[b]{2}{*}{9715} & \multirow{2}{*}{$\begin{array}{c}(0.021 \\
) \\
16021\end{array}$} & \multicolumn{5}{|c|}{$(0.024$} \\
\hline & & & & & 6306 & 9715 & 16021 & 6306 & 9715 \\
\hline \multicolumn{10}{|c|}{ Panel B: Education } \\
\hline & Total & $\begin{array}{l}<9 \\
\text { Yrs. }\end{array}$ & $\geq 9$ Yrs. & Total & $\begin{array}{l}<9 \\
\text { Yrs. }\end{array}$ & $\begin{array}{l}\geq 9 \\
\text { Yrs. }\end{array}$ & Total & $\begin{array}{l}<9 \\
\text { Yrs. }\end{array}$ & $\begin{array}{l}\geq 9 \\
\text { Yrs. }\end{array}$ \\
\hline ATET & $\begin{array}{c}0.010 * * \\
* \\
(0.003)\end{array}$ & $\begin{array}{l}0.010 * * \\
(0.005)\end{array}$ & $\begin{array}{c}0.010 * * \\
(0.005)\end{array}$ & $\begin{array}{c}0.050^{*} \\
* \\
(0.021 \\
)\end{array}$ & $\begin{array}{c}0.061 * * \\
(0.027)\end{array}$ & $\begin{array}{c}0.032 \\
(0.025 \\
)\end{array}$ & $\begin{array}{c}0.047 * \\
* \\
(0.024 \\
)\end{array}$ & $\begin{array}{c}0.046 \\
(0.031)\end{array}$ & $\begin{array}{c}0.042 \\
(0.028 \\
)\end{array}$ \\
\hline $\begin{array}{c}\text { Observatio } \\
\text { ns }\end{array}$ & 16021 & 9197 & 6824 & 16021 & 9197 & 6824 & 16021 & 9197 & 6824 \\
\hline \multicolumn{10}{|l|}{ Panel C: Age } \\
\hline & Total & $\begin{array}{l}\leq \mathbf{3 9} \\
\text { Yrs. }\end{array}$ & $\begin{array}{l}>39 \\
\text { Yrs. }\end{array}$ & Total & $\begin{array}{l}\leq \mathbf{3 9} \\
\text { Yrs. }\end{array}$ & $\begin{array}{l}>39 \\
\text { Yrs. }\end{array}$ & Total & $\begin{array}{l}\leq \mathbf{3 9} \\
\text { Yrs. }\end{array}$ & $\begin{array}{l}>39 \\
\text { Yrs. }\end{array}$ \\
\hline ATET & $\begin{array}{c}0.010 * * \\
* \\
(0.003)\end{array}$ & $\begin{array}{l}0.005 * \\
(0.003)\end{array}$ & $\begin{array}{c}0.019 * * \\
* \\
(0.006)\end{array}$ & $\begin{array}{c}0.050^{*} \\
* \\
(0.021 \\
)\end{array}$ & $\begin{array}{l}0.038 * \\
(0.021)\end{array}$ & $\begin{array}{c}0.062 * \\
* \\
(0.031 \\
)\end{array}$ & $\begin{array}{c}0.047 * \\
* \\
(0.024 \\
)\end{array}$ & $\begin{array}{l}0.035^{*} \\
(0.020)\end{array}$ & $\begin{array}{c}0.061 * \\
(0.037 \\
)\end{array}$ \\
\hline $\begin{array}{c}\text { Observatio } \\
\text { ns }\end{array}$ & 16021 & 8859 & 7162 & 16021 & 8859 & 7162 & 16021 & 8859 & 7162 \\
\hline $\begin{array}{l}\text { Household } \\
\text { Ch. }\end{array}$ & Yes & Yes & Yes & Yes & Yes & Yes & Yes & Yes & Yes \\
\hline $\begin{array}{c}\text { Municipalit } \\
\text { y Ch. }\end{array}$ & Yes & Yes & Yes & Yes & Yes & Yes & Yes & Yes & Yes \\
\hline
\end{tabular}

Table A4: Heterogeneous Effects for Pro-Social Behavior - Private Social Capital

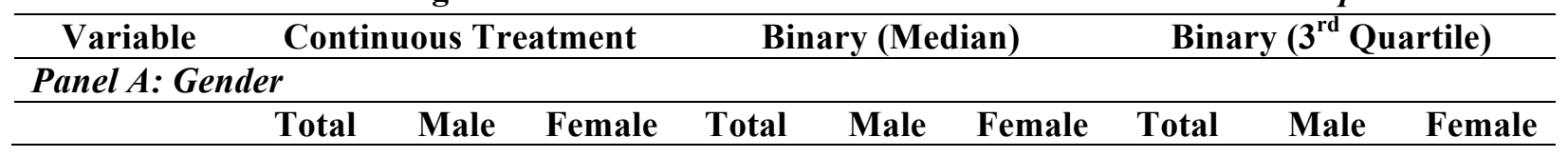




\begin{tabular}{|c|c|c|c|c|c|c|c|c|c|}
\hline ATET & $\begin{array}{l}-0.002 \\
(0.005)\end{array}$ & $\begin{array}{c}-0.002 \\
(0.005)\end{array}$ & $\begin{array}{l}-0.002 \\
(0.006)\end{array}$ & $\begin{array}{c}-0.013 \\
(0.029)\end{array}$ & $\begin{array}{l}-0.023 \\
(0.037)\end{array}$ & $\begin{array}{l}-0.007 \\
(0.030)\end{array}$ & $\begin{array}{c}0.004 \\
(0.029)\end{array}$ & $\begin{array}{l}-0.026 \\
(0.032)\end{array}$ & $\begin{array}{c}0.025 \\
(0.035)\end{array}$ \\
\hline Observations & 16020 & 6306 & 9714 & 16021 & 6306 & 9715 & 16020 & 6306 & 9714 \\
\hline \multicolumn{10}{|c|}{ Panel B: Education } \\
\hline & Total & $\begin{array}{l}<9 \\
\text { Yrs. }\end{array}$ & $\geq 9$ Yrs. & Total & $\begin{array}{l}<9 \\
\text { Yrs. }\end{array}$ & $\geq 9$ Yrs. & Total & $<9$ Yrs. & $\geq 9$ Yrs. \\
\hline ATET & $\begin{array}{l}-0.002 \\
(0.005)\end{array}$ & $\begin{array}{c}-0.002 \\
(0.005)\end{array}$ & $\begin{array}{l}-0.002 \\
(0.007)\end{array}$ & $\begin{array}{c}-0.013 \\
(0.029)\end{array}$ & $\begin{array}{c}-0.003 \\
(0.034)\end{array}$ & $\begin{array}{l}-0.030 \\
(0.034)\end{array}$ & $\begin{array}{c}0.004 \\
(0.029)\end{array}$ & $\begin{array}{l}-0.002 \\
(0.033)\end{array}$ & $\begin{array}{c}0.014 \\
(0.036)\end{array}$ \\
\hline Observations & 16020 & 9196 & 6824 & 16021 & 9197 & 6824 & 16020 & 9196 & 6824 \\
\hline \multicolumn{10}{|l|}{ Panel C: Age } \\
\hline & Total & $\begin{array}{l}\leq \mathbf{3 9} \\
\text { Yrs. }\end{array}$ & $\begin{array}{l}>39 \\
\text { Yrs. }\end{array}$ & Total & $\begin{array}{l}\leq \mathbf{3 9} \\
\text { Yrs. }\end{array}$ & $\begin{array}{l}>39 \\
\text { Yrs. }\end{array}$ & Total & $\begin{array}{l}\leq \mathbf{3 9} \\
\text { Yrs. }\end{array}$ & $\begin{array}{l}>39 \\
\text { Yrs. }\end{array}$ \\
\hline ATET & $\begin{array}{l}-0.002 \\
(0.005)\end{array}$ & $\begin{array}{l}-0.005 \\
(0.007)\end{array}$ & $\begin{array}{c}0.001 \\
(0.005)\end{array}$ & $\begin{array}{l}-0.013 \\
(0.029)\end{array}$ & $\begin{array}{l}-0.016 \\
(0.033)\end{array}$ & $\begin{array}{c}-0.009 \\
(0.035)\end{array}$ & $\begin{array}{c}0.004 \\
(0.029)\end{array}$ & $\begin{array}{l}-0.006 \\
(0.038)\end{array}$ & $\begin{array}{c}0.015 \\
(0.032)\end{array}$ \\
\hline Observations & 16020 & 8858 & 7162 & 16021 & 8859 & 7162 & 16020 & 8858 & 7162 \\
\hline $\begin{array}{l}\text { Household } \\
\text { Ch. }\end{array}$ & Yes & Yes & Yes & Yes & Yes & Yes & Yes & Yes & Yes \\
\hline $\begin{array}{c}\text { Municipality } \\
\text { Ch. }\end{array}$ & Yes & Yes & Yes & Yes & Yes & Yes & Yes & Yes & Yes \\
\hline
\end{tabular}

